\title{
Cultural heritage markets: are traders traitors? Winners and losers from cross-border shifts of historical artefacts
}

\author{
Octavian-Dragomir JORA \\ The Bucharest University of Economic Studies, Bucharest, Romania \\ octavian.jora@rei.ase.ro \\ Matei-Alexandru APĂVĂLOAEI \\ The Bucharest University of Economic Studies, Bucharest, Romania \\ matei.apavaloaei@rei.ase.ro \\ Mihaela IACOB \\ The Bucharest University of Economic Studies, Bucharest, Romania \\ mihaela.iacob@fin.ase.ro
}

\begin{abstract}
The concept of cultural heritage covers the tangible and intangible things bequeathed from the past generations along with a spiritual signification, beyond any other serviceableness. Anthropologists, sociologists, philosophers and aesthetes are the critical reviewers of the field, while legalists and economists contribute with their own concerns: regulation and evaluation. Be it of tangible nature - i.e., buildings, sites, paintings, sculptures or various other artefacts - or of an intangible one - i.e., traditions, practices, beliefs, literary or musical compositions -, the cultural heritage has challenged the economists urging them to offer sophisticated tools to assess its value, to make cost-benefit analyses with respect to its preservation, restoration or reuse. The supporters of regulation in the cultural goods market justify it through the fact that the market cannot provide in an efficient manner this type of goods, the solution being national government intervention - i.e., for the regulation and finance of cultural/heritage goods - or even international government regulation, in cases when national states' failure is encountered. A widespread opinion is that heritage is communal, par excellence, this view implicitly adjusting the acceptation that private property has in the cultural realm. The present paper addresses the reality and the necessity of ownership and movement of heritage goods especially in the international markets, considered as a dangerous vacuum for national cultural treasuries.
\end{abstract}

Keywords: cultural heritage, property rights, national regulations, international trade, heritage goods.

Please cite the article as follows: Jora, O., Apăvăloaei, M. and Iacob, M. (2018), "Cultural heritage markets: are traders traitors? Winners and losers from cross-border shifts of historical artefacts", Management \& Marketing. Challenges for the Knowledge Society, Vol. 13, No. 2, pp. 897-912, DOI: 10.2478/mmcks-2018-0012.

\section{Introduction}

Civilization, representing the interplay of cultures, is a vast structure of production. Within it, individuals, communities, nations - parts of a sole human species - express, share, reconcile and strengthen their values and attitudes, beliefs and convictions, habits and customs, artefacts and craftsmanship, as spirit and matter co-work for this (Jora, 2016). Both popular wisdom and scientific literature devoted to the economics of culture host, among other related aspects, an implicit/explicit "double conceptual 
dualism", with substantial repercussions in the palpable reality, for instance, when dealing with the moral and legal regime of the goods storing cultural value and pertaining to various (inter)national stocks (and flows). Nota bene: in the present paper, we will refer only to cultural tangible/material goods because any spiritual value whatsoever can exist only attached to a piece of solid matter. Higher values and beliefs do not belong to the etheric realm of free-floating beings, but are embodied in our physical, mental possessions and processes, and in our external prolongations, in the form of resources that we transform from the state of nature, endowing them with spiritual connotations. The above-mentioned double dualism with respect to cultural tangible goods refers, on the one hand, to property vs. heritage (as conceptual approaches concerning the representation of the cultural belongings) and, on the other hand, to humankind's vs. nation's property/heritage (as proper moral/legal jurisdictions where property issues are assessed and addressed).

The difference between cultural property and cultural heritage supposedly resides in the fact that the second term rather overrides (or it "should") the first one, infusing it with a meaning without which it allegedly is too unconvincing; putting it otherwise, intellectual and spiritual accumulations and achievements of a society are poorly covered by the word "property". Heritage (patrimony) is said to express better the idea of successional transfer among generations, through communitarian and careful protection and preservation, of the "social meanings", which is the very essence of culture; putting it otherwise, the widespread utilitarian logic of (private) property translates, in cultural matters, in reifying and mercantile behaviors. Turning now to the "geo-cultural order", cultural property/heritage may be seen either as belonging to humanity (regardless of origin or current location, of ownership or jurisdiction - spirit promoted internationally by the 1954 Hague Convention for the Protection of Cultural Property in the Event of Armed Conflict) or as indivisible portion from a nation's/state's culturally living body (here, the "kinship" prevails over the "species", as nation-states become the tutor and curator of all cultural inland production as well as overseas circulation - spirit associated to the 1970 UNESCO Convention on the Means of Prohibiting and Preventing the Illicit Import, Export and Transfer of Ownership of Cultural Property). These approaches are depicted as rather complementing each other than being in conflict, despite obviously different implications.

The present paper explores the rationales for considering cultural products as compatible with the logic of the free market, finding inbuilt compatibility between private (much more than public) property rights (and contractual freedom) and the freedom of cultural expression (also) in the realm of cultural "public goods". Accordingly, the freedom to trade internationally will be analyzed in parallel with the idea of cultural exchanges, observing virtuous and vicious circles emerging in the global scenery, where the needs for identity preservation face or fuse with those for diversification of experiences. The paper is organized into four parts that are meant to progressively address the space for cultural expression in the logic of genuinely free (rather than state-distorted) market institutions. Part I will discuss the problem of culture as tributary (despite elevated, spiritual objectives) to earthly scarcity of resources, whose freedom of disposal affects/defects the culture of a society. Part II will contain a very brief inventory of the most common provisions that are associated 
with the public regulation - i.e., the regime of ownership - of artistic, cultural heritage goods. Part III will recollect some figures relevant to the problem of worldwide mobility of the cultural heritage assets, sketching an image of the recent years' economic geography of cultures. Part IV will reveal arguments from cultural nationalists asking for heritage protectionism (export bans), explaining that they fail to achieve increases in the cultural welfare and wealth of nations.

\section{Property in cultural expression: markets or hierarchies} Property rights, economic systems, and culture(s)

Cultural heritage is defined, by the United Nations' specialized agency devoted to the promotion of international collaboration through educational, scientific, and cultural reforms, as "the legacy of physical artefacts and intangible attributes of a group or society that are inherited from past generations, maintained in the present and bestowed for the benefit of future generations" (UNESCO). The cultural heritage of any human society plays a crucial role for its members; it allows them to gain a sense of identity by adhering to a set of shared values and by accepting a common historical interpretation of the past. Common identity helps individuals better tackle uncertainty and potential conflicts by simply taking recourse to this common ground: cultural heritage. In this sense, cultural heritage enters in fecund resonance with the universal/civilizational institution of property/ownership, mainly in its tangible, "artefactual" dimension.

Property rights provide an orderly response to the problems scarcity poses to society, helping the latter in minimizing conflictuality and maximizing cooperation, minimizing waste and maximizing wealth. Naturally, societies do not function solely on the basis of "atomistic" private property rights, being perfectly compatible with commonly owned resources. Individuals must adopt viable rules and accept legitimate leaders to play a role in administering the co-owned resources. But, here, one must clearly distinguish between (private) governance and (mere) government. The first form of organization is characterized by voluntarily accepted rules and social elites that emerge from the bottom up, while the latter is based on coercion, expropriation and hierarchical edicts imposed on a community (Hoppe, 2001). The domain of cultural heritage management cannot escape these basic social caveats and choices.

In the cultural sphere, property rights also serve as a disciplinary device, given the fact that even if cultural artefacts embed "commonly shared values", they are primarily part of every individual's own, intimate valuation "schemes". Individual preferences are demonstrated in action (in "culture", as in any social expression); the concatenations of individual preferences are realized in markets, based on property rights. The success or the failure of certain cultural expressions is a function of spiritual, symbolical vibration as it is one of the price-signaled availability of scarce material, tangible resources. Still, regardless of whether we agree (or we are happy) with letting cultural life at the mercy of mundane forces, this is a fact; market value and cultural value can be educated to converge. Voluntary validation of cultural artefacts is more in the spirit of a free society, assessed either nationally or globally (Cowen, 2000; Cantor, 2012).

Under a free market/laissez-faire/capitalist order, the prevailing tendency is toward greater output and a greater variety of cultural products (the intrinsic moral 
and aesthetic quality of which remain a highly debatable issue). Free market tends to send to the dustbin of history the works not enough beloved by the general public or not in the graces of the patrons of arts, as it also tends to improve critical wisdom. Taking these judgments as benchmark, the impact of state interventionism can be assessed beyond the narrative that "official elites" can eradicate a Ruskin-type "cultural market failure". Tastes cannot be improved forcefully (not even by employing milder means, as supposed by funding "fine culture" by tax revenues); moreover, the state may (and historically it did) act as a deterrent for artistic criticism. Besides suspicions on state-corrupted cultural guilds, "unintended consequences" of good intentions are present.

\section{Property institutional arrangements and heritage}

Solution 1: NGO - private, but non-profit. The NGO sector is seen as a hybrid solution that tempers in a private, voluntary framework both the hyper-onerous businessspecific behaviors and the bureaucratic lethargy specific to the politico-administrative environment. Culture-oriented NGOs provide "public goods" with wide social accessibility in exchange for resources entrusted to them freely by private actors, based on a consolidated reputational basis, as well as by public funds and/or fiscal and regulatory facilities coming from the government (Seaman, 2013).

Solution 2: privatizing cultural heritage. The "for profit" privatization has at least the same pertinent reasons as NGO administration (Rojas, 2001; Gibson, 2009). For example, in the Italian public debate, the main pros invoked were: (1) reducing pressure on public budgets; (2) decreasing production costs; (3) maximizing efficiency of privatized entities; (4) improving supply of goods and services to the public; (5) diminishing political influence in resource allocation decisions; (6) enhancing scope for market-based, entrepreneurial actions (Ponzini, 2010).

Solution 3: volunteering for cultural heritage. Economists have recognized the role played in community development by involving people through their work and dedication without claiming direct material compensation. It is considered that although the value of the voluntary labor force is not calculated as part of the national gross income, in some countries this contribution would exceed their gross domestic product. According to UNESCO statistics, thousands of such volunteers are involved annually in cultural heritage preservation or restoration projects (Da Milano, 2008).

Private-public (anti-)synergies (crowding-out and crowding-in). Evictions can occur both ways: private/public funders can reduce their investment because they can appreciate that the public/private support is enough and that further involvement would not yield significant benefits to the investor. At the same time, a phenomenon contrary to crowding-out, a "synergistic" one, may occur: the state/private agents can "export" credibility towards each other, each of one's presence attracting the other one's involvement that otherwise would have been reluctant.

\section{Regulating the cultural heritage: in and between nations Cultural heritage laws within nations}

The legal codification of a societal concern is usually perceived as proof of the maturity of understanding it. However, it should be noted the "positive law" / "legislation" is always subject to critical scrutiny under the auspices of the (natural) 
logic of law. A common sense evaluation of a certain piece of law is its coherence and consistency with the (praxeo)logical sense of property rights. It ought to be investigated whether "the legal concept of property rights corresponded to the catallactic concept" (Mises, 1998), that is granting to the rightful owners (individuals or groups) full control over their property, which was acquired by homesteading, productive work and voluntary transfer of titles (Rothbard, 1982). The cultural goods cannot escape the need for such clarifications and legal protection against both "private" and "public" injuries.

In historical order, the legislative endeavors devised to protect cultural heritage are of an age with "our era". Emperor Vespasian (1st century AD) called himself "protector of the public edifices and a restorer of the private ones" (Lazăr, 2007: 191), issuing first pieces of legislation addressing cultural matters. The Hellenic-Latin art apex was followed by a Dark Age cultural "hibernation" ended by Renaissance; in the ruins of ancient Rome's empire the power of memories blew up. Trajan's Column was declared by an 1162 papal edict "a monument for eternity", "never be destroyed or mutilated [...] to the honor of the Roman people, until the end of the world" (Luca, 1999: 25). Holding a huge stock of vestiges, targets of incipient "archaeological looting", the medieval Italian city-states took organized measures to protect their ancient cultural legacy.

The first significant piece of legislation is considered the decree of Pope Pius II (1464) prohibiting the removal from the Vatican of works of art. Seven decades later, Pope Paul III set up the "Antiquities Commissariat", the first public institution of this kind in history. The Renaissance brought with it an expansion of the interest and means of preserving the past works of art in the private collections of the Italian nobility, acting for their custodians as an indicium nobilitatis and testimonies of their ancestry roots in the Roman age. In the XVII and XIX centuries, the European aristocracy and bourgeoisie set themselves culturally in the new world geography: if the great discoveries had brought only barbarity, the memory of the old Mediterranean cradle (Egyptian, Greek, Roman) was a needed spiritual anchor for the European civilization.

In the XIX century, the "great age of amateur archaeologists" began, and along with it the trade of antiquities, whose outlets were museums, universities, commercial and political elites, with a particular concentration in Paris and London. Napoleonic France, then Wilhelminian Germany exceled in institutions dedicated to the protection of heritage, amid the imperialist-nationalistic composite accents, specific to the statutes of great powers. But young nations were also taking action in this respect. The Romanian principalities responded to this trend: in 1860, the Commission for Historical and Archaeological Research was established, empowered to research and record cultural and artistic assets; in 1892, in full process of national (cultural) modernization, Romania passed the "Law for the preservation of public monuments".

In the second half of the XX century, the international market for cultural goods was experiencing an unprecedented development, beyond the narrow circle of public museums and wealthy private collectors and connoisseurs. On a cyclical world economic background, with significant fluctuations in the value of traditional movable and immovable assets, cultural goods began to be sought as quite suitable investments to better store "economic value". All the segments of this cultural 
artefacts market are now booming: the "white" segment (the official one, of the big auction houses), the "black" segment (of the first hand "smugglers") and the "grey" segment (of the intermediaries). The present global siege upon global cultural heritage is thought to be a function of greed and power as of institutional ill-design or mal-enforcement.

The contemporary cultural heritage law, embodied by domestic legislation as well as international agreements, expanded in response to the risk of transforming objects of heritage into a smuggled commodity to the detriment of, ultimately, their preservation and thus possibility of being cherished by the peoples of the world. Nowadays, UNESCO framework dominates the cultural heritage international law, addressing issues of protection, cooperation, rectification, criminal justice and dispute resolution, complemented by the fundamental law of international trade (the "WTO Agreement"), which accommodates in its non-discriminative rhetoric a discriminatory treatment for "national cultural treasuries" (Nafziger and Paterson, 2014).

\section{Cultural heritage laws across nations}

Merryman (1986) notes that although both the 1954 Hague Convention for the Protection of Cultural Property in the Event of Armed Conflict and the 1970 UNESCO Convention on the Means of Prohibiting and Preventing the Illicit Import, Export and Transfer of Ownership of Cultural Property aim to protect the cultural property/heritage, each of them attaches to the term "protection" different meanings, embodying different and somewhat dissonant sets of values. The distinction lies in the particularity of the objectives of each of the two documents: one dealing with the protection of cultural assets by the actions of the belligerent parties in times of military conflict, and the other with the illicit trafficking of heritage goods. But the difference seems to be more profound than the one coming from the specificity of the objectives, reflecting fundamental differences in the philosophy of cultural justification, with effects in the format of international regulations targeting cultural heritage.

For example, the preamble to the 1954 Hague Convention speaks of the cultural heritage of mankind. The 1970 UNESCO Convention, in its preamble, but also in the rest of the document, emphasizes the interest of states in the national cultural heritage. The 1954 Hague Convention seeks to protect cultural property from deterioration or destruction. The 1970 UNESCO Convention strives for the nations' custody over cultural property. The two accents - one cosmopolitan, another nationalist; one for protection, the other for preservation - characterize the two major ways of thinking of cultural property. As such, one can speak of "cultural internationalism" as opposed to "cultural nationalism" (the latter being the dominant view). In many cases, the two approaches support each other, but they can also go in divergent ways. The distinction cultural nationalism - cultural internationalism becomes significant when denouncing "destructive retention" or "greedy neglect".

Nationalism and cultural internationalism also differ in their responses to the practice of storing cultural objects and facilitating access to them. Many artefacts of ancient civilizations are retained by some states, on their national territory, although these cultures are abundantly present in both public museums and private collections. Such surplus of artefacts is just stored without sometimes even being catalogued, 
inventoried and made available to the public and to the researchers either from that country or from abroad. Museums in other states that lack such works would be willing to acquire, study and expose them, while also preserving them. Foreign dealers and collectors would also be happy to buy them and extend circulation. Cultural nationalism translates into the bulk storage of unused artefacts, despite that there is a global "market" from which all parties ("interested", not "idle", collectors, researchers, and visitors) may therefore benefit.

Cultural internationalism recommends that cultural objects be made available worldwide by sales, exchanges or rentals. The achievements of ancient cultures in the countries of origin could be exposed to a broader audience, responding to the interest of foreigners to see and study such works (part of mankind's cultural heritage) and partially meeting the demand (which otherwise is covered by the illicit market) through open and legal exchange of cultural property. It is suspected that many countries of origin retain duplicates of cultural artefacts beyond any imaginable need, refusing to make them available to foreign museums, collectors, dealers; by banning exports, no use is made of what is retained, losing also positive spill-overs. A country is wealthy not necessarily in the obsolete mercantilist way, by "storing" value within its borders, but by putting it to wider circulation, thus ensuring its replenishing. "Cultural popularity" is an intangible production factor.

Another criticism of cultural nationalism is that by legally forbidding and restricting lawful trade in cultural property, the black, illicit market is encouraged, while the 1970 UNESCO Convention naively thinks the opposite. There are two (contradictory and competing) hypotheses: on the one hand, for the countries of origin and UNESCO, the existence of illicit trade justifies additional and stronger legal controls; on the other hand, for the critics of this approach, extending legal controls only feeds the illegal traffic, the whole process entering a perilous and wasteful escalation. Empirically viewed, heritage-looting is far from being discouraged. It would be more accurate to say that it has been proliferating. The effects are the transaction costs for "prohibition", but also the heavy negative externalities for the goodwill cultural heritage consumers (significant risks of artefact destruction during the smuggling operations) and for taxpayers (more inefficient public spending).

If it is true that the demand for cultural objects necessarily implies the emergence of illicit traffic to some extent, so the arguments for controlled legalization of exploration and exploitation become, at least, noteworthy. The question arises whether it might be better if, for instance, digging in archaeological sites (i.e., the case of the quest for golden Dacian bracelets and Kosons in Romania) is done openly, turning illegality and dilettantism into legality and professionalism. This could avoid unnecessary physical damages and excavation work would be documented. In other words, the money spent on clandestine excavations, bribes on police and customs officers, acting as fraudulent "rents" extracted by "entrepreneurs" who speculate this hoax, would be better used if they served transparently supporting the work of archaeologists, anthropologists and other specialists, as well as the effort of the former clandestine diggers that become, from then on, legal workers. 


\section{Civilization as cultural diversity: on ex/changing values} From "cultural homeland security"...

Modern and contemporary world of nation-states has found another raison d'État in "cultural security". Questioning its importance is considered an offence, as it is also the case with the traditional territory raptures. As said, the states are divided, with respect to cultural artefacts circulation, into origin-states for cultural goods and outletstates (with transit-states as intermediate). The dialectic replicates the classical economic "producer-merchant-consumer" chain: in origin-countries, the supply exceeds the demand, whereas in outlet-countries, the case is reversed, and the principle of communicating vessels is doing its job inexorably, moving them from the first category to the second. Egypt, Greece, India or Mexico are exporters for the enjoyment of "Western capitalist aristocrats" (located in countries such as Switzerland, France, Germany, Japan, the Scandinavian states, United Kingdom and United States of America) and for the Persian Gulf "petro-sheiks" or "novi ruski" oligarchs.

For national accounts representations, the (un)balances of cultural trade can be calculated, but they can only emphasize the elementary intuition, as well as inflame the nationalist spirits. The question of protectionism is being raised - an inverted protectionism, blocking trade at the expeditor, not at the recipient. While other forms of export are frenetically encouraged, the cultural one upturns dialectic. Domestic laws prohibit or limit exports of goods from the "national cultural heritage", and international agreements reinforce the vigilance, few nations being lax in this respect (for example, the US and Switzerland, this precisely due to their net positive cultural trade balance). The reasons of cultural protectionism (Ginsburgh and Mairesse, 2013) range from the "romantic Byronism" of getting back home the identity effigies, to political uses of the cultural heritage symbolism, to the lack of expertise and management regarding the exploitation of this valuable resource, to vested interests towards prohibition, for huge rents can be extracted from cultural looting.

The international flow of cultural heritage goods is regulated by a number of self-standing treatise and international conventions, but also by special provisions that amend the general rules that apply to most other goods (Nafziger and Paterson, 2014). For instance, according to WTO rules, the "General Exceptions" stipulated in Article XX of the GATT exempt cultural goods from the interdiction of applying any prohibition to the export or import of goods - the so-called "National Treasuries" clause. The exemption reads as follows: "Subject to the requirement that such measures are not applied in a manner which would constitute a means of arbitrary or unjustifiable discrimination between countries where the same conditions prevail, or a disguised restriction on international trade, nothing in this Agreement shall be construed to prevent the adoption or enforcement by any contracting party of measures:... (f) imposed for the protection of national treasures of artistic, historic or archaeological value". But the cultural commerce is part of the dialogue of nations. 
Table 1. Top 10 exporters of heritage goods \& rest of the world, USD, 2016

\begin{tabular}{llrr} 
No. & Country & $\mathbf{2 0 1 6}$ & Share \\
\hline 1 & United Kingdom & $1,364,511,471$ & $36 \%$ \\
2 & USA & $899,047,709$ & $24 \%$ \\
3 & France & $312,981,349$ & $8 \%$ \\
4 & China, Hong Kong & $292,588,657$ & $8 \%$ \\
5 & Switzerland & $272,330,494$ & $7 \%$ \\
6 & Germany & $183,161,585$ & $5 \%$ \\
7 & Austria & $81,465,146$ & $2 \%$ \\
8 & Saudi Arabia & $43,686,988$ & $1 \%$ \\
9 & Belgium & $35,796,139$ & $1 \%$ \\
10 & Canada & $33,466,373$ & $1 \%$ \\
11 & Rest of the World & $250,350,182$ & $7 \%$ \\
& $\quad$ Share of Top 10 & & $\mathbf{9 3 \%}$ \\
\hline
\end{tabular}

Source: UN Comtrade.

Table 2. Top 10 importers of heritage goods \& rest of the world, USD, 2016

\begin{tabular}{llrr} 
No. & Country & $\mathbf{2 0 1 6}$ & Share \\
\hline 1 & USA & $1,699,436,845$ & $33 \%$ \\
2 & United Kingdom & $1,159,832,725$ & $22 \%$ \\
3 & China, Hong Kong & $834,969,269$ & $16 \%$ \\
4 & Switzerland & $294,617,007$ & $6 \%$ \\
5 & Netherlands & $268,770,942$ & $5 \%$ \\
6 & France & $179,962,333$ & $3 \%$ \\
7 & Germany & $172,182,138$ & $3 \%$ \\
8 & Japan & $79,995,062$ & $2 \%$ \\
9 & Austria & $55,061,557$ & $1 \%$ \\
10 & China & $40,917,766$ & $1 \%$ \\
11 & Rest of the World & $404,745,241$ & $8 \%$ \\
& $\quad$ Share of Top 10 & & $\mathbf{9 2 \%}$ \\
\hline
\end{tabular}

Source: UN Comtrade.

Historically viewed, the heritage goods market has been very concentrated, the Top 10 importers and exporters (mostly the same) making up more than $90 \%$ of the entire value of transactions (see Table 1 and Table 2). This contributes to a more accurate image that defies hasty intuitions about (underdeveloped) countries systematically depleted of their treasuries to the benefit of (developed) others. When looking at the 2016 situation for each nation (Figure 1), we can see that there is no correlation between income per capita and the country's position as a net importer or net exporter of heritage goods. We can observe that the countries that have an approach closer to the free market stance when it comes to the international flow of heritage goods are located to the right of the graph, meaning that they have high volumes of both exports and imports, while countries that have a more inwardlooking policy are situated closer to the Oy axis. 


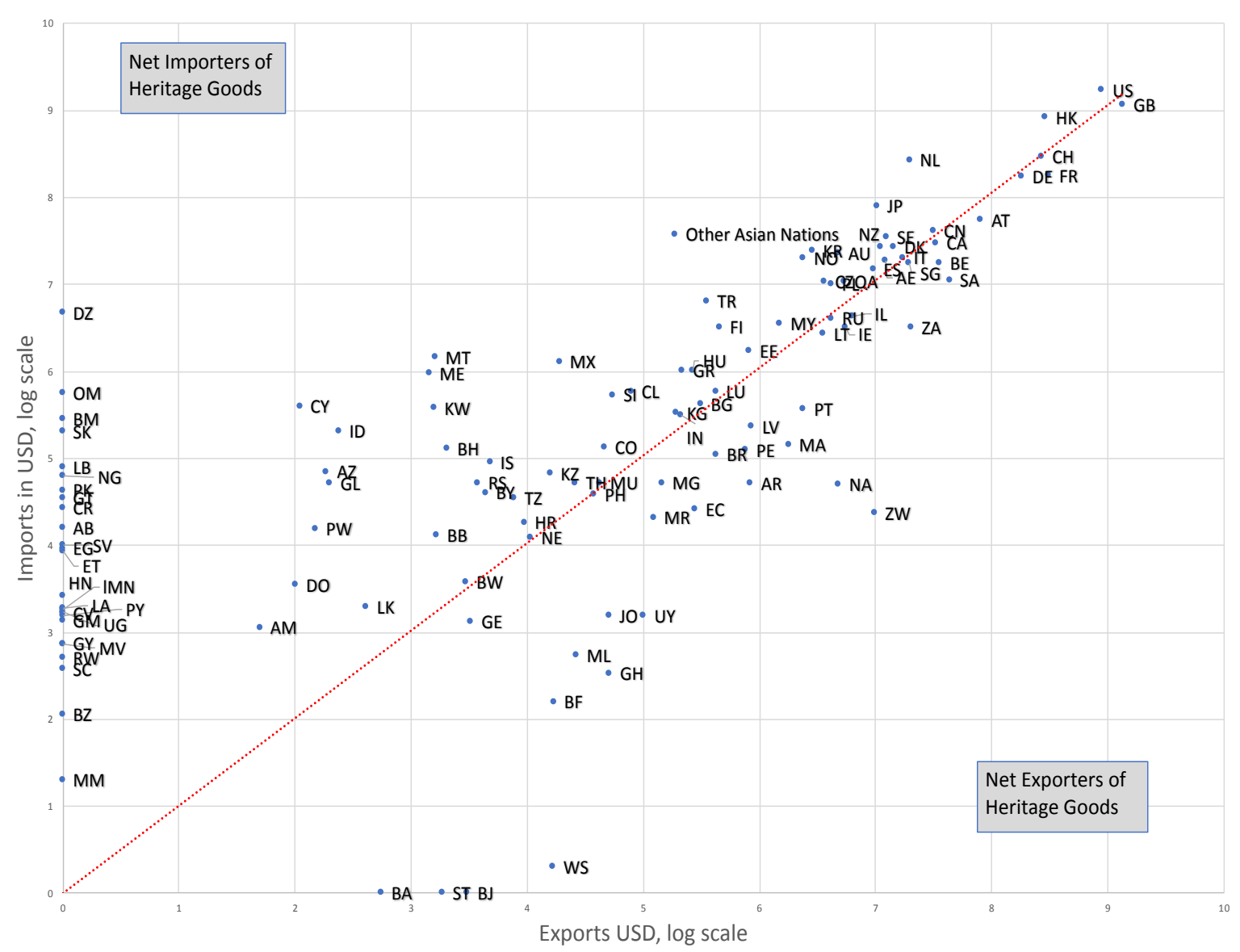

Figure 1. Heritage goods imports \& exports, by country (117 countries, 2016, USD, log scale)

Source: UN Comtrade.

\section{...To "cultural cross-borders liberty"}

According to the 2009 UNESCO Framework for Cultural statistics (UNESCO, 2009: 6572), international trade of cultural goods can be split into six categories: (a). cultural and natural heritage (antiques); (b). performance and celebration (musical instruments, recorded media); (c). visual arts and crafts (paintings, other visual arts, crafts, jewellery); (d). books and press (books, newspapers, other printed media); (e). audio-visual and interactive media (film and video); (f). design and creative services (architecture and design). Out of these six categories, only the first element in the list refers to cultural heritage goods. As we can note from the below figures, category (a) has represented, over the last ten years, around $3 \%$ of the total value of cultural goods imports and exports, most certainly, the low trade volumes registered for these goods being definitely caused by the prohibitions and regulations specific for this field. 


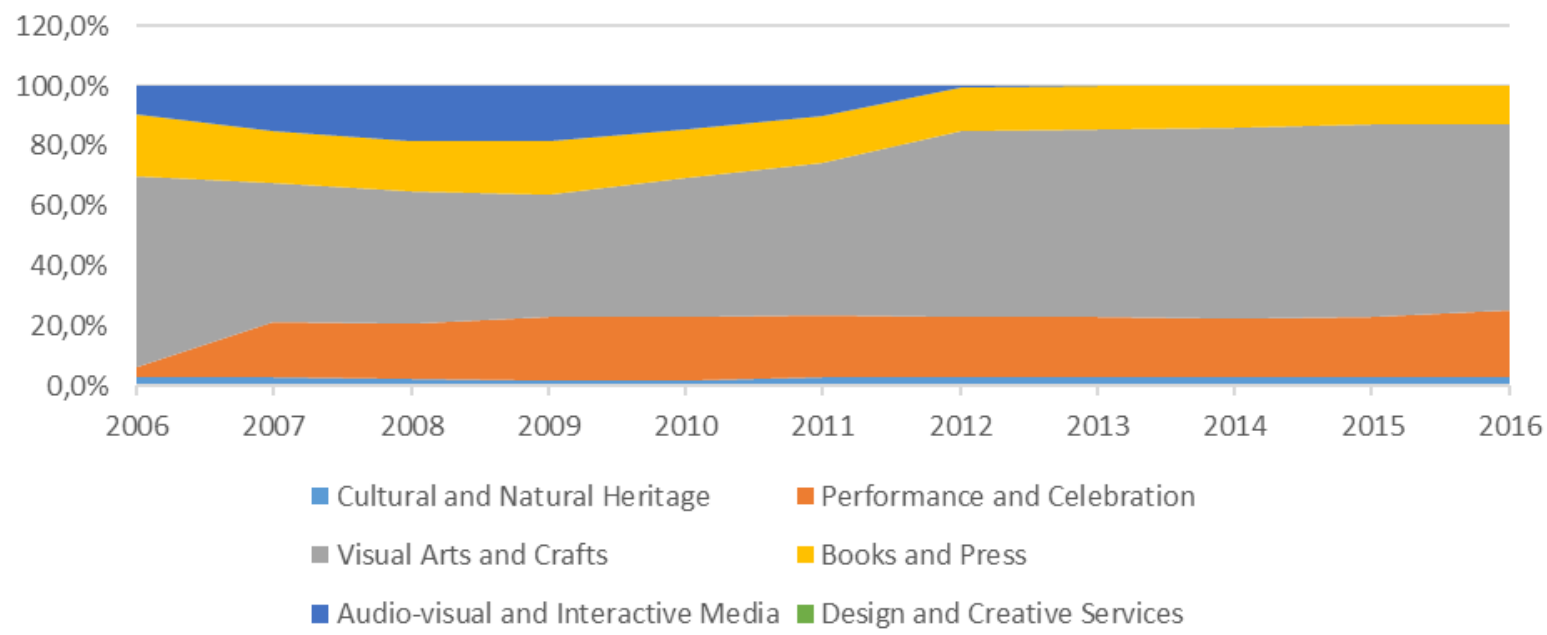

Figure 2. World cultural goods exports (share of each category, \%)

Source: UN Comtrade.

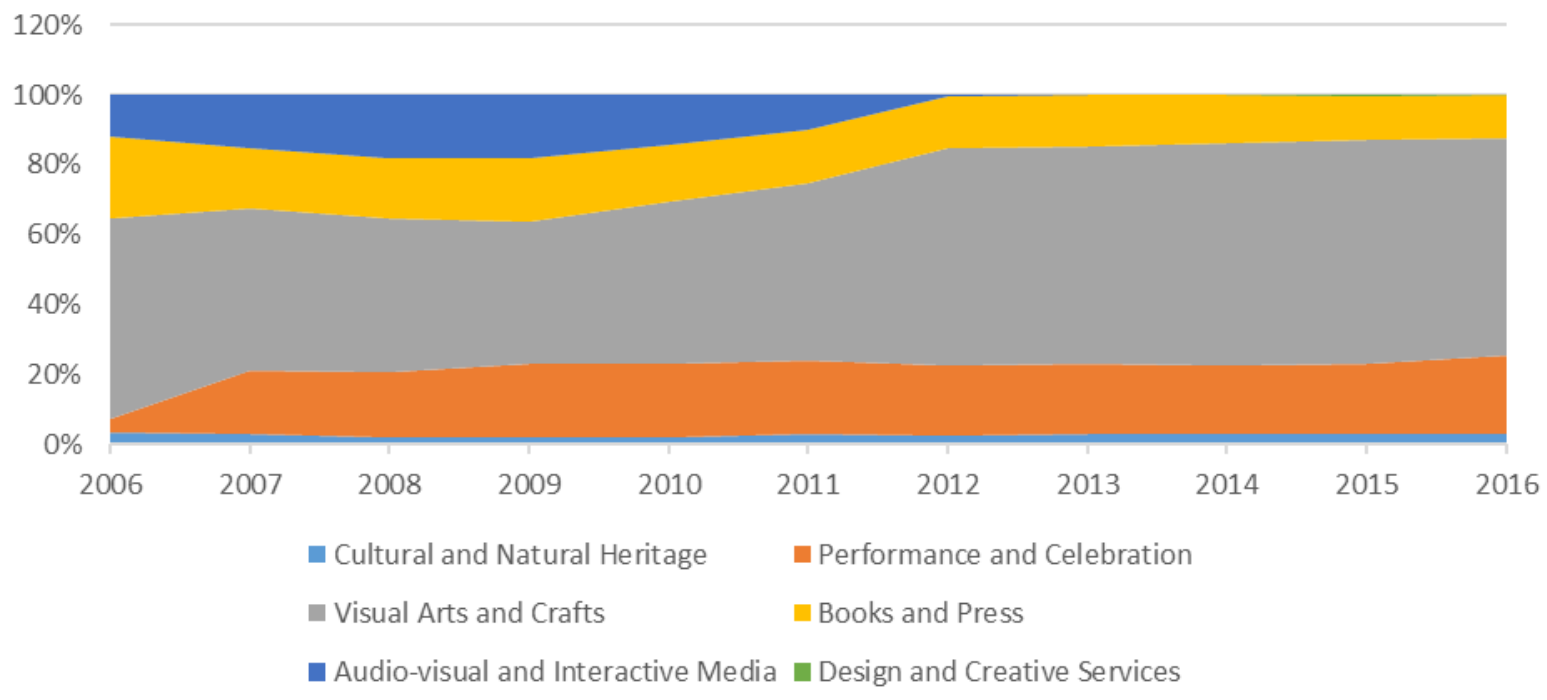

Figure 3. World cultural goods imports (share of each category, \%)

Source: UN Comtrade,

Adding into the landscape the income per capita factor, the next question naturally arises: are heritage goods sold mainly by the relatively poor countries in order to finance their trade deficits? By looking at the distribution of cultural goods by domain and income level, one may become alarmed by the high share represented by heritage goods in cultural goods export volumes. For the entire period between 2006 and 2016, exports of heritage goods made up around $40 \%$ of the cultural goods exports value from low-income countries, but only $0.2 \%$ of imports. If one were to look only at the above figures, he might draw the conclusion that low-income countries are providing the bulk of the heritage goods that are traded on the world markets. But such a conclusion is definitely a hasty one, since it does not take into account the actual value (relatively small) of these outflows of goods that is exiting in developing countries. 
- Cultural and Natural Heritage

- Visual Arts and Crafts

Audio-visual and Interactive Media
- Performance and Celebration

Books and Press

- Design and Creative Services

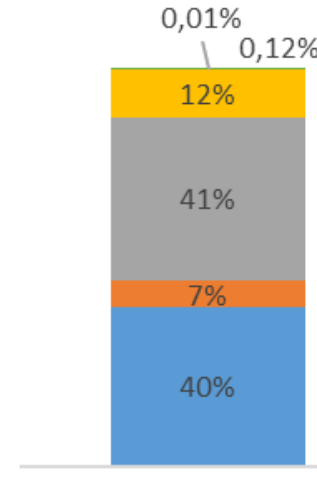

Low income

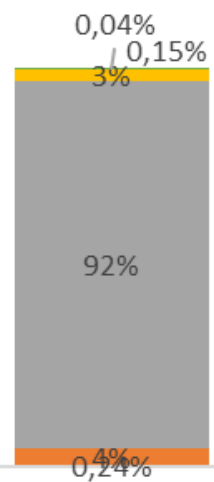

Lower middle income

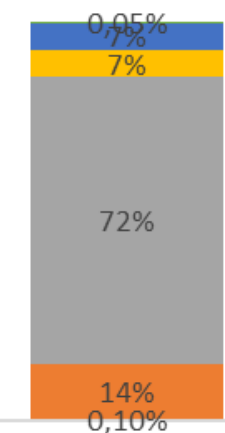

Upper middle income

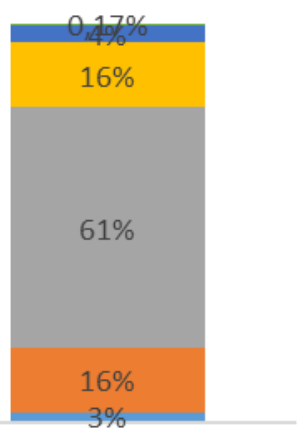

High income

Figure 4. Distribution of cultural goods exports by domain and income (2006-2016, \%)

Source: UN Comtrade and WB.
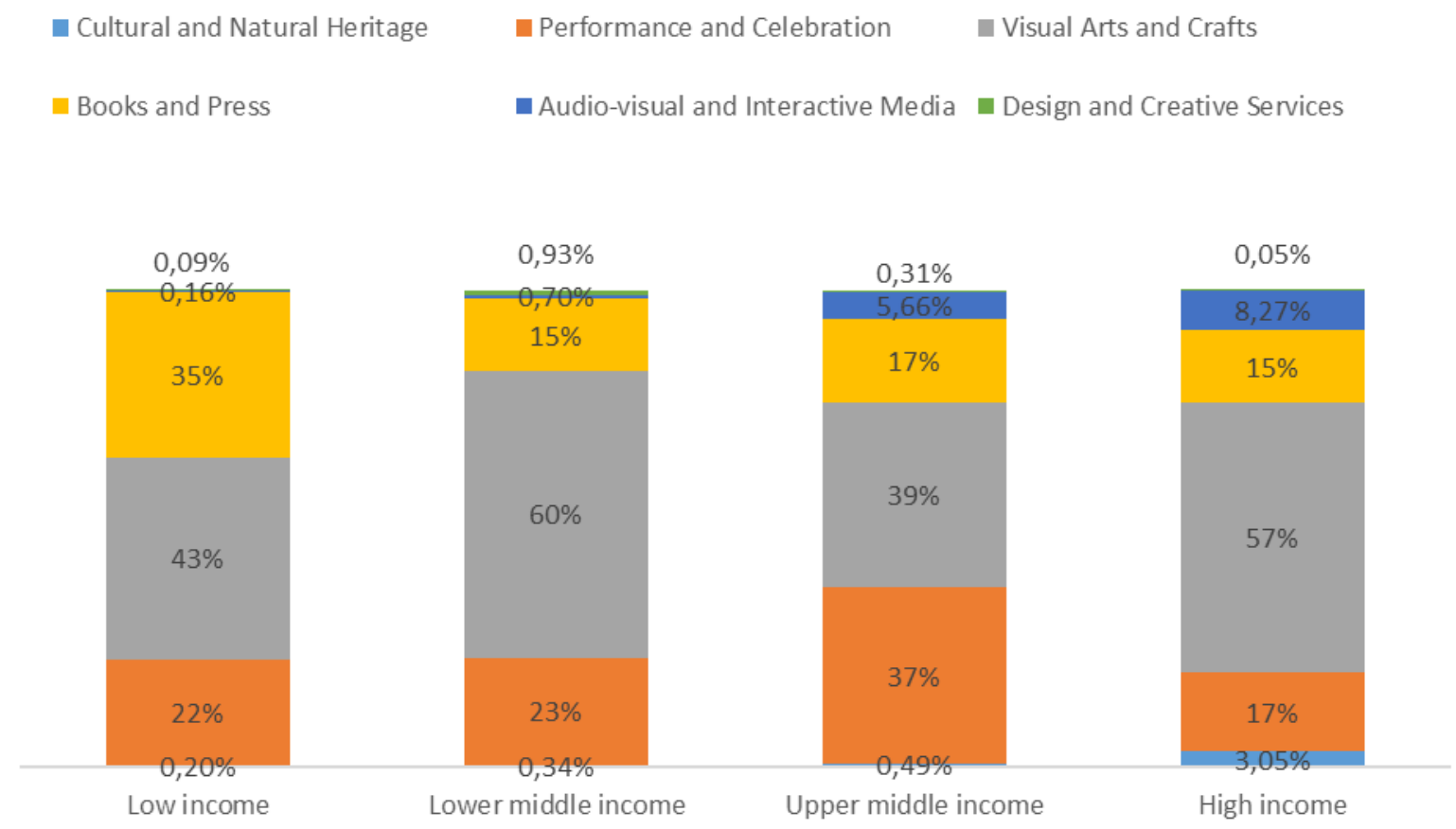

Figure 5. Distribution of cultural goods imports by domain and income (2006-2016, \%)

Source: UN Comtrade and WB.

Segregating value of imports and exports of heritage goods according to their place of origin, we can see that high-income countries actually make up for $97 \%$ of both trade flows, while developing countries make up for a mere $0.69 \%$ of exports and $0.02 \%$ of imports. Therefore, the drain of heritage goods from developing countries is not as accelerated as it first seemed. The high share that the export of heritage goods had in the overall cultural goods exports of low-income countries can more readily be explained by the low value of the former. Nevertheless, the cultural bias of bemoaning

Vol. 13, No. 2, Spring pp. 897-912, ISSN 1842-0206 | Management \& Marketing. Challenges for the Knowledge Society 
the (risk of) depletion of national cultural heritage from relatively less developed countries in favour of the most developed ones defies figures (even if figures per se cannot account for the ethical grounds). The solution to such deficits boils down to soundly define property rights and to allow utility to be maximized by free trade.

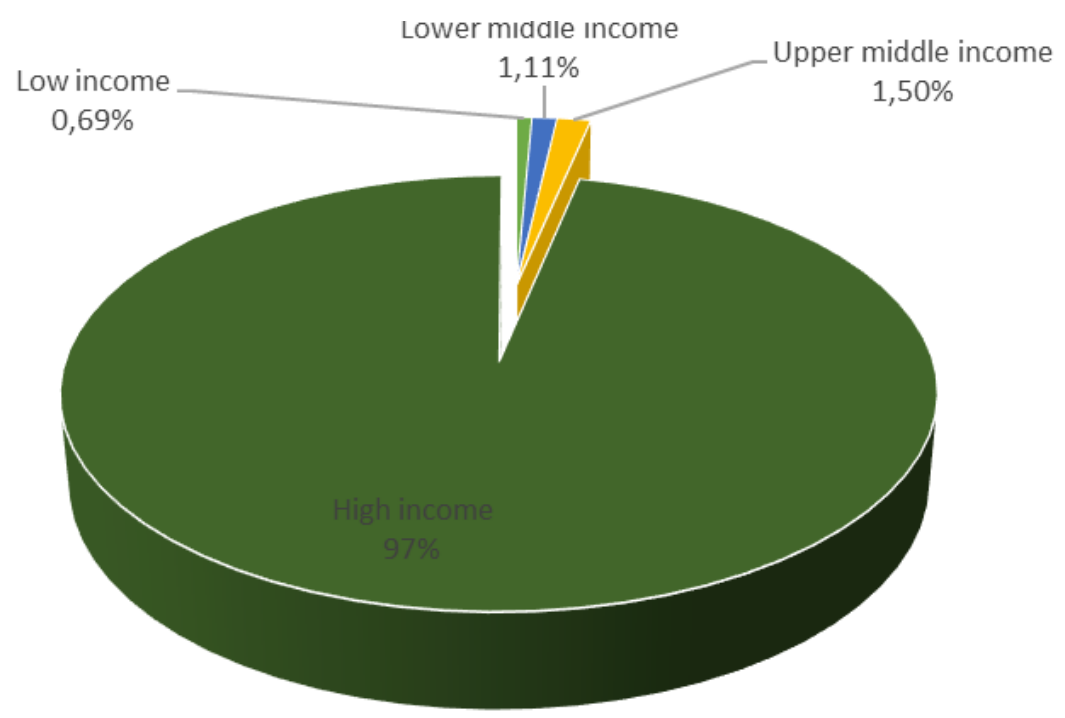

Figure 6. Export values share of cultural and natural heritage goods (2006-2016, \%)

Source: UN Comtrade and WB.

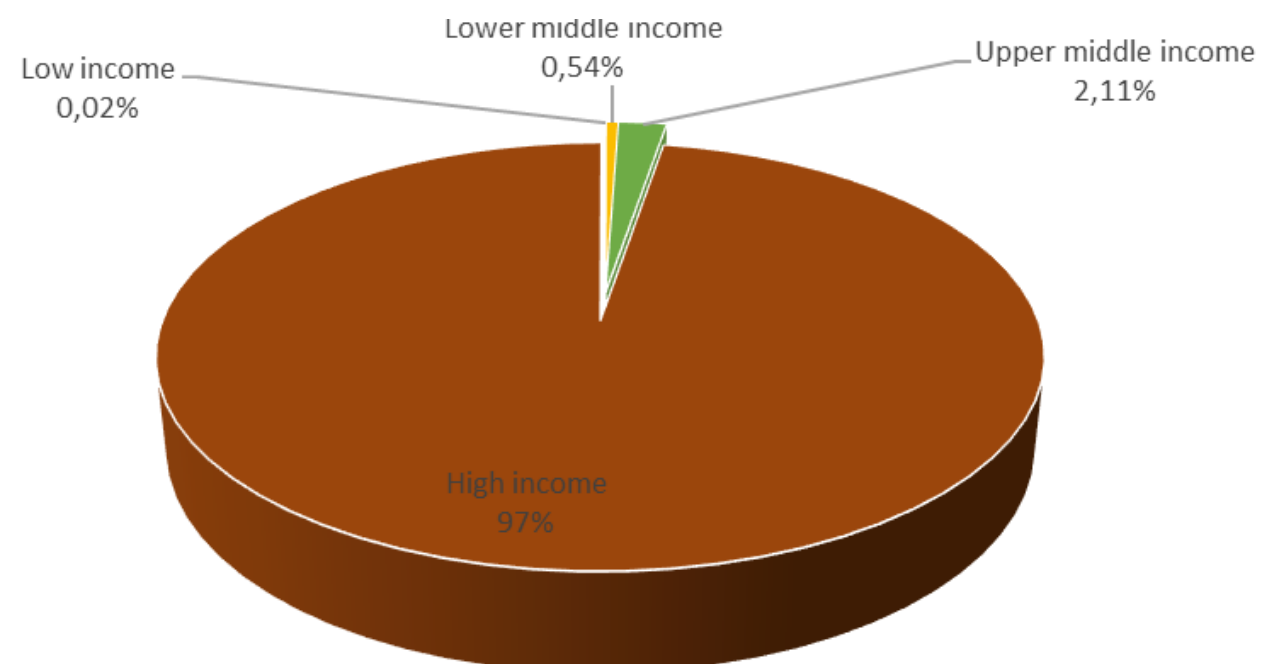

Figure 7. Import value share of cultural and natural heritage goods (2006-2016, \%)

Source: UN Comtrade and WB.

\section{Viewing (un-)fairness in the freedom of trading heritage Cultural freedom of trade and the balance argument}

One argument coming from cultural nationalists in favour of limiting free trade of cultural heritage goods says that the free trade of others lasts only insofar their balances look well (they have "good" deficits, importing and retaining more cultural assets than exporting). To this "hypocritical freedom", the response would be preemptive protectionism. But this reasoning misses the point that such a policy shift 
does not hurt only the potential future foreign buyers of heritage goods. The burden produced by a prohibition of this sort is going to disproportionately fall upon those domestic individuals that have accumulated a stock of heritage goods (as investment), and that may want to sell it in the future. It is the affluent citizens of those protectionist countries that will feel the brunt of such measures. However, the adoption of such an opportunistic policy is not going to be as easy as presumed, as insights provided by "the logic of collective action" (Olson, 2002) indicate. According to this approach, a small number of individuals that suffer the concentrated costs of a political policy can efficiently organise to block the enactment of this legislation. A small body of art collectors has the upper hand in setting an effective lobby action when compared with the efforts of various "loose" cultural stake-holders. Export bans hamper the chance of other countries to repatriate their historical national goods on voluntary/purchase basis, thus spurring international animosities. Not to mention the impetus to black markets that destroy transparency of and accessibility to heritage assets.

\section{Cultural freedom of trade and the poverty argument}

The argument of "cultural infancy" as a reason for "trade openness" adopted by certain countries also misses the target. On the one hand, this argument ignores the fact that countries with relatively few indigenous artefacts may still have a (merchantable) stock of accumulated foreign artefacts. On the other hand, such a critique does not take into consideration another aspect: the ultimate relativity and subjectivity of (cultural) values. It is true that the US does not have as many or as imposing ancient artefacts originated on the North American continent, but this does not mean that it lacks heritage goods dating from its so vibrant XVIII century. For instance, the writing desk of a "Founding Father" may be worth more than an ancient Phoenician statue. Also, the very fact that some countries have a relatively "shorter history" means that the number of available artefacts is lower, so they are scarcer, and therefore they may command a relatively higher price. Perhaps such countries do not have artefacts from a certain period, or they have a less plentiful stock of such goods that they can sell, but precisely because of this the few heritage goods they do possess command higher prices. More importantly, it is those countries that allegedly do have only a "short history" that are in danger of losing the few cultural heritage items they store within their borders, while the fact that the cultural panic is still absent from the public discourse may be because they endorse a less rigid and more vivid vision on how a culture is made from the interplay of worldwide cultures.

\section{Conclusions}

In this paper, we suggest that, if governments aspire to stand a better chance of repatriating the heritage goods that have been exported to other countries, the best policy to follow is one of free trade. Prohibitions can only push the international flow of heritage goods in the black market, and at the same time raise the price of those heritage goods that have already reached foreign territories. By encouraging free trade, the scarcity of these goods will be reduced. This will tend to lower prices as well as eliminate speculative stockpiling of heritage goods by foreign collectors. As a result, governments that seek to repatriate heritage goods will be in a better position to bid 
for those artefacts that they deem to be of the utmost importance and that have already left the country. Even if such a policy will result in fewer objects being concentrated in a given country, at least it would increase the chance of repatriating, on a voluntary, market basis those artefacts that are acknowledged as most valuable to each nation's heritage.

We have also looked at the composition, volume and geographic direction of the trade flow in heritage goods and cultural goods. We saw that more liberal countries account for more significant volumes of both imports and exports. Also, we saw that less developed countries and middle-income countries account for only a tiny part of international trade flows in heritage goods and consequently are not faced with an imminent drain of such artefacts. We also remarked that heritage goods represent only a small category of the more encompassing concept of trade in cultural goods. If one does not fixate exclusively on heritage goods but on cultural goods in general, then free trade is again the answer. Additionally, one must not ignore that some of the now traded cultural goods will become, with the passing of time, heritage goods in their own right. A more plentiful supply of present cultural goods means more fully-fledged heritage goods in the future, this is to the benefit of the cultural communities of our civilization.

\section{References}

Cantor. P.A. (2012), The Invisible Hand in Popular Culture: Liberty vs. Authority in American Film and TV, Lexington, KY: The University of Kentucky.

Cowen, T. (2000), In Praise of Commercial Culture, Harvard University Press: Cambridge, MA.

Da Milano, C. (2008), "Volunteering for cultural heritage in Europe", in Da Milano, C., Gibbs K. and Sani, M. (eds.), Volunteers for Cultural Heritage: A European Handbook, pp. 9-22, Slovene Museum Association: Ljubljana.

Gibson, K. (2009), "Profit from the priceless: heritage sites, property rights and the duty to preserve", Business and Society Review, Vol. 114, No. 3 (Fall 2009), pp. 327-348.

Ginsburgh, V. and Mairesse, F. (2013), "Issues in the international market for cultural heritage", in Rizzo, I. and Mignosa, A. (eds.), Handbook on the Economics of Cultural Heritage, pp. 151-170, Edward Elgar: Cheltenham, UK, Northampton, MA, USA.

Hoppe, H.H. (2001), Democracy: The God That Failed, Transaction Publishers: New Brunswick, NJ.

Jora, O.D. (2016), Spiritualitate, materialitate și proprietate. Cultura mea, cultura ta, cultura noastră, cultura lor [Spirituality, materiality and property. My culture, your culture, our culture, their culture], Editura ASE: București.

Lazăr, A. (2007), "Metodologia investigării infracțiunilor contra patrimoniului cultural national" [Methodology of investigation for crimes against national cultural heritage], Revista Drept - Series Jurisprudentia, Vol. 10, pp. 191-206.

Luca, S.A. (1999), Arheologia generală (prima parte) [General Archaeology (first part)], Editura Altip: Alba Iulia.

Merryman, J.H. (1986), "Two Ways of Thinking About Cultural Property", The American Journal of International Law, Vol. 80, No. 4 (Oct. 1986), pp. 831-853. 
Mises, L. von. ([1949] 1998), Human Action. A Treatise on Economics (the scholars' edition), Ludwig von Mises Institute: Auburn, AL.

Nafziger, J.A.R. and Paterson, R.K. (2014), "International Trade in Cultural Material”, in Nafziger, J.A.R and Paterson, R.K. (eds.), Handbook on the Law of Cultural Heritage and International Trade, pp. 19-44, Edward Elgar: Cheltenham, UK.

Olson, M. (2002), The Logic of Collective Action, Public Goods and the Theory of Groups, Harvard University Press: Cambridge, MA.

Ponzini, D. (2010), "The Process of Privatization of Cultural Heritage and the Arts in Italy: Analysis and Perspectives", International Journal of Heritage Studies, Vol. 16, No. 6 (Oct. 2010), pp. 508-521.

Rojas, E. (2001), "Revitalization of Historic Cities with Private Sector Involvement: Lessons from Latin America", in Serageldin, I., Shluger, E. and Martin-Brown, J. (eds.). Historic Cities and Sacred Sites: Cultural Roots and Urban Futures, pp. 391-400. The World Bank: Washington DC.

Rothbard, M.N. ([1982] 1998), Ethics of Liberty, New York University Press: New York, NY.

Seaman, B.A. (2013), "The Role of the Private Sector in Cultural Heritage", in Rizzo, I. and Mignosa, A. (eds.), Handbook on the Economics of Cultural Heritage, pp. 111-128. Edward Elgar: Cheltenham, UK, Northampton, MA, USA.

*** Convention for the Protection of Cultural Property in the Event of Armed Conflict, The Hague. (14 May 1954). http://portal.unesco.org/en/ev.phpURL_ID=13637\&URL_DO=DO_TOPIC\&URL_SECTION=201.html [Accessed: 31.10.2017].

*** http://www.worldbank.org/ [Accessed: 31.10.2017].

*** https://comtrade.un.org/ [Accessed: 31.10.2017].

*** The 2009 UNESCO Framework for Cultural Statistics (FCS). (2009). UNESCO Institute for Statistics. http://unesdoc.unesco.org/images/0019/001910/191061e.pdf [Accessed: 31.10.2017].

*** UNESCO Convention on the Means of Prohibiting and Preventing the Illicit Import, Export and Transfer of Ownership of Cultural Property, Paris. (14 November 1970). $\quad$ http://portal.unesco.org/en/ev.phpURL_ID=13039\&URL_DO=DO_TOPIC\&URL_SECTION=201.html [Accessed: 31.10.2017]. 